\title{
Buoyancy and growth characteristics of three positively buoyant marine diatoms
}

\author{
J. Keith Moore ${ }^{1, *}$, Tracy A. Villareal ${ }^{2}$ \\ ${ }^{1}$ College of Oceanic and Atmospheric Sciences, Oregon State University, 104 Oceanography Administration Building, \\ Corvallis, Oregon 97331-5503, USA
}

${ }^{2}$ Environmental Sciences Program, University of Massachusetts, 100 Morrissey Blvd, Boston, Massachusetts 02125-3393, USA

\begin{abstract}
The growth rates and buoyancy properties of 3 oceanic diatoms in the genus Rhizosolenia were examined at light levels from 8 to $211 \mu \mathrm{mol}$ quanta $\mathrm{m}^{-2} \mathrm{~s}^{-1}$ Maximum growth rates ranged from 0.37 to 0.78 divisions $\mathrm{d}^{-1}$ with saturation occurring between 29 and $164 \mu \mathrm{mol}$ quanta $\mathrm{m}^{-2} \mathrm{~s}^{-1}$ Severe growth rate depressions were noted in $R$. acuminata and $R$. formosa at irradiance levels above 50 to $155 \mathrm{kmol}$ quanta $\mathrm{m}^{-2} 5^{-1}$ In all 3 species the percentage of positively buoyant cells was inversely related to light intensity. In $R$. formosa both growth rate and tolerance to high light levels decreased substantially as cell size decreased. Batch culture C:chlorophyll ratios (130 to 261) replicated values found in field Ethmodiscus and Rhizosolenia mats, and suggest that the elevated C:chlorophyll ratios found in buoyant, oceanic phytoplankton are typical of healthy cells. Calculations suggest that carbohydrate ballasting can account for buoyancy changes and that these reserves are adequate to support dark $\mathrm{NO}_{3}{ }^{-}$uptake. Under steady-state conditions in situ, the observed growth and buoyancy properties would lead to subsurface population maxima in all 3 species. However, the dynamic light-related buoyancy changes probably occur on a shorter time scale than these batch culture experiments. These results indicate that vertical migration is a property basic to these diatoms life history strategy, and, like multispecies Rhizosolenia mats, solitary Rhizosolenia chains transport new nitrogen to the euphotic zone in oligotrophic seas
\end{abstract}

KEY WORDS: Rhizosolenia - Buoyancy Chemical composition - Growth rates - New nitrogen Suspension - Vertical migration

\section{INTRODUCTION}

Rhizosolenia formosa $\mathrm{H}$. Peragallo, $R$. acuminata $(\mathrm{H}$. Pera.) H. Peragallo and $R$. castracanei H. Peragallo are chain-forming marine diatoms which thrive under the low-turbulence, nutrient-poor conditions typical of the open ocean gyres (Karsten 1905, 1907, Sundström 1986). These large diatoms (up to $10^{8} \mu^{3}$ ) should be at a severe competitive disadvantage in obtaining nutrients relative to small $(<5 \mu \mathrm{m})$ phytoplankton due to their lower surface/volume ratio (Chisholm 1992). Other large phytoplankton in the same environment, such as Pyrocystis noctiluca and the multispecies Rhizosolenia mats, overcome this size-related disad-

•E-mail: jmoore@oce.orst.edu vantage by obtaining nutrients from below the nutricline through a buoyancy-mediated vertical migration (Rivkin et al. 1984, Hayward 1993, Villareal et al 1993). This strategy exploits spatially uncoupled light and nutrient fields (Ganf \& Oliver 1982) and avoids direct nutrient competition with smaller size fractions. Positive buoyancy is a prerequisite for vertical migration, but has traditionally been considered unlikely or aberrant in diatoms due to the relatively high density of the frustule (Smayda 1970, Walsby \& Reynolds 1980 Round et al. 1992). However, numerous diatoms characteristic of the open sea such as Ethmodiscus spp. and solitary Rhizosolenia spp. are capable of positive buoyancy (Villareal 1988, 1992, Villareal \& Carpenter 1989), and the evidence strongly suggests that they also migrate vertically (Villareal 1992, Villareal \& Carpenter 1994, Villareal \& Lipschultz 1995) 
This migratory behavior has strong relevance to oceanic biogeochemistry in addition to basic autecological problems. Since vertical migrators directly transport $\mathrm{NO}_{3}{ }^{-}$into the upper mixed layer, they circumvent the $\mathrm{NO}_{3}{ }^{-}$trap at the base of the euphotic zone (Banse 1987) and represent a source of 'new nitrogen' (Dugdale \& Goering 1967) to the euphotic zone (Villareal et al. 1993) Calculations suggest that vertically migrating Rhizosolenia mats could transport nitrogen equal to $2-27 \%$ of the turbulent upward flux of nitrate in the central Pacific gyre (Villareal et al. 1993). Such inputs would supply some fraction of the new nitrogen required to support the sub-surface oxygen maximum common in oceanic gyres (Hayward 1994); however, quantitative estimates are difficult due to the limited abundance data available. Moreover, the time scale for migration is uncertain but is almost surely less than the carbon specific doubling rates of these taxa in surface waters (Villareal \& Carpenter 1994).

Such life history parameters are difficult to determine from field populations and diatom vertical migration has been studied using internal $\mathrm{NO}_{3}{ }^{-}$pools, buoyancy changes and $\delta^{15} \mathrm{~N}$ signature to infer behavior and past history (Villareal et al. 1993, Villareal \& Lipschultz 1995). However, mechanistic understandings can only be derived from laboratory studies that evaluate to which nutritional or environmental variables buoyancy is responding. In addition, the relationships between light, chemical composition and growth rate require clarification since the literature suggests these large phytoplankton have unusually high C:chlorophyll ratios (Villareal \& Carpenter 1989, 1994). We therefore undertook a series of experiments to examine selected growth, chemical composition and buoyancy properties of Rhizosolenia formosa and $R$. acuminata, $R$. castracanei. We wanted to determine if vertical migration by single-species diatom chains was feasible, and to examine the buoyancy responses to various environmental factors which might permit this migration. To investigate the influence of light on buoyancy, we measured the buoyancy of all 3 species under steadystate, nutrient-replete conditions over a range of light intensities. This experiment was repeated 3 times over a 10 mo period using the $R$. formosa clone to examine how changing cell size affected buoyancy/light interactions. Compositional characteristics of $R$. formosa and $R$. acuminata at different light levels were also examined. The effects of changing light levels on buoyancy were examined in $R$. formosa over a diel cycle and for a period of several days. All of the Rhizosolenia spp. in this study are capable of positive buoyancy and are sometimes members of Rhizosolenia mats, thus the results may also provide insight into the physiological mechanisms of mat vertical migration (Villareal et al. 1993).

\section{MATERIALS AND METHODS}

Culture and analytical methods. Rhizosolenia formosa H. Peragallo (clone B8), R. acuminata (H. Pera) $H$. Peragallo (clone G3) and $R$. castracanei $H$. Peragallo (clone G12) were isolated from the Sargasso Sea near Bermuda in August 1992 ( $R$. formosa) or in September 1993 (others). Cells were hand-collected using SCUBA techniques and isolated in modified MET 44 medium (Schöne \& Schöne 1982, Villareal 1991). Cell cultures were unialgal and grown under a $12: 12 \mathrm{~h}$ light:dark cycle in 2 or 2.51 polycarbonate bottles at $21^{\circ} \mathrm{C}$. Species identification was made according to Sundström (1986).

Cell buoyancy was measured using a petri dish. A homogeneous sample was poured into the bottom half of the petri dish and the inverted lid was gently slid across the top so as to exclude air bubbles. After turbulence subsided $(\sim 5 \mathrm{~min})$, most cells rested against the top or bottom dish; their buoyancy was operationally defined as positive or negative, respectively. A small percentage of cells drifting between the top and bottom dish were defined as neutrally buoyant. Cells were counted using an Olympus $\mathrm{SZH}$ stereoscope. Cell size was measured with an Olympus BH-2 compound light microscope. Cell volumes were calculated assuming a cylindrical shape.

Nitrate, phosphate, silicate and ammonium concentrations in the medium and cell sap were measured using a TRAACS 800 autoanalyzer. To measure extracellular nutrient concentrations, samples were syringefiltered $(0.8 \mu \mathrm{m}$ pore size polycarbonate filter) and frozen in an acid-washed plastic scintillation vial for later analysis. For measuring intracellular nutrient concentrations, samples were filtered onto $0.8 \mu \mathrm{m}$ pore size polycarbonate filters, rinsed with approximately $5 \mathrm{ml}$ of a nitrate-free synthetic seawater and frozen in $5 \mathrm{ml}$ of distilled water in acid-washed plastic scintillation vials. Upon thawing, the vials were placed in a boiling water bath for 5 min to rupture cells and extract intracellular nutrients.

Samples for total protein, carbohydrate, particulate carbon and nitrogen were filtered onto pre-combusted ( $2 \mathrm{~h}$ at $400^{\circ} \mathrm{C}$ ) GF/F glass fiber filters. Chlorophyll samples were collected on GF/F filters. Carbohydrate and chlorophyll were frozen in foil and protein samples were frozen in plastic sample vials. Particulate $C$ and $N$ were frozen in pre-combusted aluminum foil and analyzed using a Perkin-Elmer 2400 CHN Elemental Analyzer. Protein samples were boiled in $0.1 \mathrm{~N} \mathrm{NaOH}$ for $1 \mathrm{~h}$ and then measured using a bicinchoninic acid assay (Smith et al. 1985, Sigma procedure no. TPRO562.). Particulate carbohydrate was measured using an anthrone reagent standardized to glucose (Parsons et al. 1984a). Chlorophyll was measured fluorometrically 
in acetone extracts (Parsons et al. 1984b). Light intensity was measured inside the culture bottles using a Biospherical Instruments, Inc., QSP170B quantum sensor with $4 \pi$ collector. Cultures were grown under cool white fluorescent light. Blue light culture bottles were wrapped in a blue plastic screening which had a broad wavelength transmission (380 to $550 \mathrm{~nm}$ ) with a peak transmission (near $80 \%$ ) at 455 to $465 \mathrm{~nm}$.

Growth rates $\left(\mu_{\mathrm{e}}\right)$ were calculated as the slope of the linear portion of in transformed cell numbers plotted against time. Divisions $\mathrm{d}^{-1}$ were calculated as $\mu_{\mathrm{e}} / \ln (2)$. Preliminary studies showed that daily sampling inhibited normal cell division, so the minimum sampling interval was every other day.

Experimental methods. Cultures of each species were pre-adapted for $10 \mathrm{~d}$ at different light levels ranging from 8 to $211 \mu \mathrm{mol}$ quanta $\mathrm{m}^{-2} \mathrm{~s}^{-1}$. White light simulated near-surface light quality at sea, and the blue light simulated the light quality that phytoplankton experience lower in the euphotic zone. The transition point varied from 30 to $40 \mu \mathrm{mol}$ quanta $\mathrm{m}^{-2} \mathrm{~s}^{-1}$ and was based primarily on the maximum irradiance that could be used with blue screening which did not overheat the samples. Buoyancy and cell numbers of all 3 species were measured periodically through the exponential growth phase. Carbon, nitrogen, carbohydrate, protein, chlorophyll, internal nitrate pools and medium nitrate concentrations were measured from Rhizosolenia formosa and $R$. acuminata during the exponential growth phase. The apparent production rate $\left(P^{\mathrm{B}}, \mathrm{mg} \mathrm{C}\right.$ $\mathrm{mg}^{-1}$ chlorophyll a $\mathrm{h}^{-1}$ ) was calculated using the observed growth rates, average $\mathrm{C}$ and chlorophyll a values, and the photoperiod.

The experiment described above was repeated 3 times over a $10 \mathrm{mo}$ period at 3 different cell sizes to examine the influence of cell size on Rhizosolenia formosa buoyancy patterns. Volume declined by $54 \%$ from the largest $\left(1.18 \times 10^{7} \mu^{3}\right)$ to the smallest cell size $\left(5.69 \times 10^{6} \mu^{3}\right)$. In another experiment, a $R$. formosa culture growing under white light at $143 \mu \mathrm{mol}$ quanta $\mathrm{m}^{-2} \mathrm{~s}^{-1}$ was divided equally between 2 polycarbonate bottles. A control remained at the relatively high light level at which the original culture had been growing; the other bottle was moved to a low-light environment at $42 \mu$ mol quanta $\mathrm{m}^{-2} \mathrm{~s}^{-1}$. Buoyancy and nutrient concentrations in the cell sap and medium were followed for $6 \mathrm{~d}$. To investigate diel patterns, a $R$. formosa culture grown in white light at 154 pmol quanta $\mathrm{m}^{-2} \mathrm{~s}^{-1}$ was sampled every $3 \mathrm{~h}$ for a $24 \mathrm{~h}$ period for buoyancy, cell sap nitrate, population and the number of cells recently divided. Recently divided cells were defined as cells in a chain with nuclei less than 1 cell diameter apart. This method allowed recently divided cells to be counted using the stereoscope at the same time as buoyancy measurements were made; thus, sample vol- ume was minimized and the buoyancy of the recently divided cells could be recorded. To prevent cell damage from frequent sampling, the culture was divided equally among 9 polycarbonate bottles $12 \mathrm{~h}$ before the experiment began, and 1 bottle was sampled at the end of each $3 \mathrm{~h}$ period.

\section{RESULTS}

The growth rate of Rhizosolenia formosa (cell diameter $=129 \mu \mathrm{m}$, average cell volume $\left.=6.58 \times 10^{5} \mu \mathrm{m}^{3}\right)$ was saturated from 23 to $58 \mu \mathrm{mol}$ quanta $\mathrm{m}^{-2} \mathrm{~s}^{-1}$ with an observed maximum of 0.37 divisions $\mathrm{d}^{-1}$ at the relatively low light level of $29 \mu \mathrm{mol}$ quanta $\mathrm{m}^{-2} \mathrm{~s}^{-1}$ (Fig. 1A). Cultures at 156 and $211 \mu \mathrm{mol}$ quanta $\mathrm{m}^{-2} \mathrm{~s}^{-1}$ died at low population densities $\left(<500\right.$ cells $\left.\mathrm{l}^{-1}\right)$ apparently due to photoinhibition. The culture growing at $106 \mu \mathrm{mol}$ quanta $\mathrm{m}^{-2} \mathrm{~s}^{-1}$ grew slowly $(0.13$ divisions $\mathrm{d}^{-1}$ ) and also died before nutrients became limiting (at -4500 cells $1^{-1}$ ). The cultures at 156 and $211 \mu \mathrm{mol}$ quanta $\mathrm{m}^{-2} \mathrm{~s}^{-1}$ died after approximately $20 \mathrm{~d}$, and the culture at $106 \mu \mathrm{mol}$ quanta $\mathrm{m}^{-2} \mathrm{~s}^{-1}$ died after about $30 \mathrm{~d}$. In all 3 high-light cultures cells underwent several divisions and appeared healthy during the first $10 \mathrm{~d}$ of the experiment. This light-induced mortality



Fig. 1 Growth rates of 3 Rhizosolenia spp. in cultures grown at different light levels. Growth rates were calculated from the average of duplicate cell counts 




Fig. 2. Percentage of Rhizosolenia cells positively buoyant in nutrient-replete, exponentially growing cultures at different light levels. All cultures had at least $10 \mathrm{~d}$ to photoacclimate before buoyancy measurement. Error bars indicate the standard deviation from 2 or 3 buoyancy measurements. $R$. formosa symbols are from a single measurement

was not observed in 2 earlier experiments when cell diameter was $176 \mu \mathrm{m}$ and average cell volume was $1.18 \times 10^{7} \mu^{3}$. At this larger cell size a growth rate of 0.45 divisions $\mathrm{d}^{-1}$ was observed at $150 \mu \mathrm{mol}$ quanta $\mathrm{m}^{-2}$ $\mathrm{s}^{-1}$, and a lower rate of 0.32 divisions $\mathrm{d}^{-1}$ was observed in a culture at $209 \mu \mathrm{mol}$ quanta $\mathrm{m}^{-2} \mathrm{~s}^{-1}$. The growth rate of $R$. acuminata (cell diameter $=122 \mu \mathrm{m}$, cell volume $=6.83 \times 10^{6} \mu^{3}$ ) increased steadily with increasing light level, to a maximum of 0.78 divisons $\mathrm{d}^{-1}$ at $155 \mu \mathrm{mol}$ quanta $\mathrm{m}^{-2} \mathrm{~s}^{-1}$, and then declined to 0.2 divisons $\mathrm{d}^{-1}$ at $212 \mu \mathrm{mol}$ quanta $\mathrm{m}^{-2} \mathrm{~s}^{-1}$ (Fig. 1B). The maximum $R$. castracanei growth rate observed was 0.38 divisons $\mathrm{d}^{-1}$ at $164 \mu \mathrm{mol}$ quanta $\mathrm{m}^{-2} \mathrm{~s}^{-1}$ (Fig. 1C). No significant photoinhibition of growth was observed at the highest light level of $210 \mu \mathrm{mol}$ quanta $\mathrm{m}^{-2} \mathrm{~s}^{-1}$.

All 3 species had an inverse relationship between positive buoyancy and light intensity under nutrient replete conditions (Fig 2). This inverse relationship was most apparent in Rhizosolenía formosa (Fig. 2A), where more than $80 \%$ of the cells were positively buoyant at the 2 lowest light levels (15 and $17 \mu \mathrm{mol}$ quanta $\mathrm{m}^{-2} \mathrm{~s}^{-1}$ ). As light level increased, the percentage of positively buoyant cells decreased; no positively buoyant cells were observed at the 2 highest light levels ( 156 and $211 \mu \mathrm{mol}$ quanta $\mathrm{m}^{-2} \mathrm{~s}^{-1}$ ). This relationship between light level and buoyancy (Fig. 2A) had the best fit linear equation, \%POS $=-4.36 \times 1+76.2, \mathrm{r}^{2}=$ 0.88 , where \%POS is the percentage of positively buoyant cells and 1 is light intensity ( $\mu$ mol quanta $\mathrm{m}^{-2}$ $\mathrm{s}^{-1}$ ). The percentage of $R$. acuminata cells positively buoyant under nutrient replete conditions was fairly constant (between 45 and 58\%; Fig. 2B) at light levels up to $110 \mu \mathrm{mol}$ quanta $\mathrm{m}^{-2} \mathrm{~s}^{-1}$; however, it declined to less than $30 \%$ at the 2 highest light levels (155 and $212 \mu \mathrm{mol}$ quanta $\mathrm{m}^{-2} \mathrm{~s}^{-1}$ ). The average percentage positively buoyant at 155 and $212 \mu \mathrm{mol}$ quanta $\mathrm{m}^{-2} \mathrm{~s}^{-1}$ was significantly lower (1-sided $t$-test, $\mathrm{p}<0.05$ ) than in the cultures at $17,38,39$ and $72 \mu \mathrm{mol}$ quanta $\mathrm{m}^{-2} \mathrm{~s}^{-1}$. Note that buoyancy patterns are similar where blue and white light cultures overlap. The best fit regression of buoyancy and light intensity in $R$. acuminata had the equation $\%$ POS $=-0.18 \times 1+61.7, \mathrm{r}^{2}=0.84$. In $R$. cas tracanei cultures, the highest percentages of positively buoyant cells were also seen in light-limited cultures (71\% at $11 \mu \mathrm{mol}$ quanta $\mathrm{m}^{-2} \mathrm{~s}^{-1}$; Fig. $2 \mathrm{C}$ ). The 2 highlight cultures had 38 and $33 \%$ positively buoyant at 164 and $210 \mu \mathrm{mol}$ quanta $\mathrm{m}^{-2} \mathrm{~s}^{-1}$, respectively. The best fit equation of this relationship (Fig. $2 \mathrm{C}$ ) had the equation $\%$ POS $=-0.15 \times l+63.1, \mathrm{r}^{2}=0.76$.

The percentage of positively buoyant Rhizosolenia formosa cells decreased over time in batch cultures (Fig. 3A). Two low- light cultures (15 and $19 \mu \mathrm{mol}$ quanta $\mathrm{m}^{-2} \mathrm{~s}^{-1}$ ) which did not reach stationary phase during the experiment had consistently high (47 to $83 \%$ ) percentages of positively buoyant cells. In the cultures at $17,23,29$ and $58 \mu \mathrm{mol}$ quanta $\mathrm{m}^{-2} \mathrm{~s}^{-1}$, the percentage of positively buoyant cells decreased from $61-83 \%$ initially to $<25 \%$ at the onset of stationary phase (cell densities between 12000 and 15000 cells $\mathrm{l}^{-1}$; Fig. 3A). Cultures grown at high light intensities (106, 156 and $211 \mu \mathrm{mol}$ quanta $\mathrm{m}^{-2} \mathrm{~s}^{-1}$ ) had consistently low percentages of positively buoyant cells $(0$ to 19\%; Fig. 3a; data not shown for 156 and $211 \mu \mathrm{mol}$ quanta $\mathrm{m}^{-2} \mathrm{~s}^{-1}$ light levels where no positively buoyant cells were observed). Buoyancy patterns over time in $R$. acuminata batch cultures also varied with light level (Fig. 3B). In the cultures at 17 and $39 \mu \mathrm{mol}$ quanta $\mathrm{m}^{-2}$ $\mathrm{s}^{-1}$ the percentage positively buoyant remained above $50 \%$ throughout the experiment; these 2 low-light, slow-growing cultures did not reach stationary phase. In faster-growing cultures (>39 $\mu \mathrm{mol}$ quanta $\mathrm{m}^{-2} \mathrm{~s}^{-1}$ ) the percentage of positively buoyant cells declined over time. High-light cultures had consistently lower percentages of cells positively buoyant. As cultures approached stationary phase, the percentage of positively buoyant cells decreased to $32 \%$ or less (Fig 3B) The percentage of $R$. castracanei cells positively buoyant also tended to decrease over time in low-light cul- 


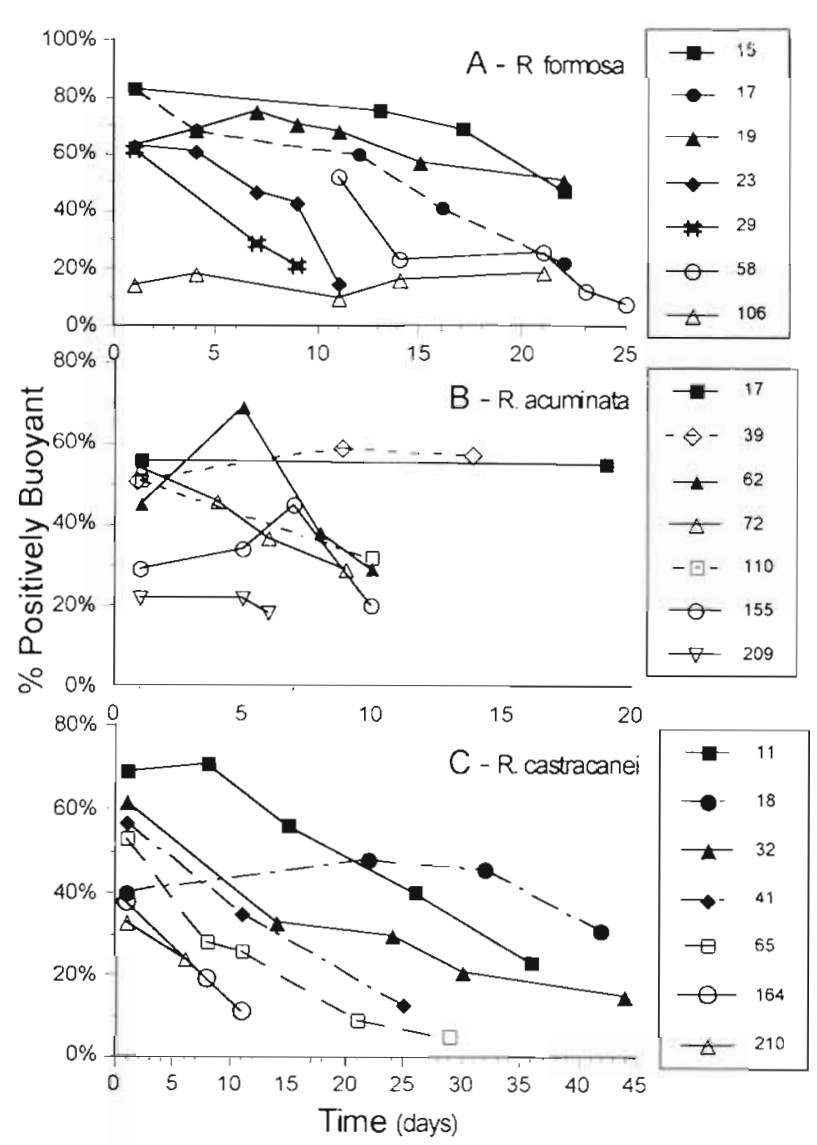

Fig. 3. Percentage of Rhizosolenia cells positively buoyant in cultures over time. Different symbols correspond to different light levels ( $\mu \mathrm{mol}$ quanta $\mathrm{m}^{-2} \mathrm{~s}^{-1}$ ). Filled symbols indicate blue light cultures, and open symbols indicate cultures growing under white light. Buoyancy measurements are from single samples $(R$. formosa), or the average of duplicate $(R$. acuminata) or triplicate samples (R. castracanei)

tures, while remaining consistently low in high-light cultures (Fig 3C). As cultures approached stationary growth phase the percentage positively buoyant declined to $<21 \%$.

Cell size also influenced buoyancy in Rhizosolenia formosa (Fig. 4). In 2 early experiments (cell diameter = $176 \mu \mathrm{m}$ ), high-light cultures (150 and $200 \mu \mathrm{mol}$ quanta $\mathrm{m}^{-2} \mathrm{~s}^{-1}$ ) exhibited no cell death from photoinhibition and had from 21 to $40 \%$ of cells positively buoyant under nutrient-replete conditions over the course of the experiments. At similar light levels (139 to $200 \mu \mathrm{mol}$ quanta $\mathrm{m}^{-2} \mathrm{~s}^{-1}$ ) the 2 smaller cell sizes (diameter $=129$ and $117 \mu \mathrm{m}$ ) had no positively buoyant cells, and the cultures died, apparently due to photoinhibition. High percentages of positively buoyant cells ( 63 to $83 \%)$ were observed at low light levels $(<20 \mu \mathrm{mol}$ quanta $\mathrm{m}^{-2} \mathrm{~s}^{-1}$ ) in experiments at the 2 smaller cell sizes. The ability to maintain positive buoyancy at high light levels appeared to decline as cell size decreased.
Note that under nutrient replete conditions (Fig. 4), positive buoyancy was observed in both high-light cultures at the largest cell size; at the intermediate cell size some positive buoyancy was observed at light levels up to $106 \mu \mathrm{mol}$ quanta $\mathrm{m}^{-2} \mathrm{~s}^{-1}$ and at the smallest cell size no positive buoyancy was observed at light levels above $32 \mu \mathrm{mol}$ quanta $\mathrm{m}^{-2} \mathrm{~s}^{-1}$. There was an inverse relationship between irradiance level and positive buoyancy at all 3 cell sizes (Fig. 4).

In the experiment where half of a Rhizosolenia formosa culture was moved to a lower light level (Day 1), the low-light culture had a sharp increase in positively buoyant cells after $5 \mathrm{~d}$ from $24 \%$ to $54 \%$, which then declined to $29 \%$ as the culture approached stationary growth phase (Fig. 5). The high-light culture had consistently low percentages of positively buoyant cells (12 to $15 \%$ ). It is unclear why growth was inhibited in the low-light culture between Days 3 and 5 . Both cultures had maximum average cell sap nitrate concentrations on Day 5 (18 and $11 \mathrm{mM}$ for the high-and lowlight cultures, respectively). Nitrate concentrations in the medium of both cultures was always greater than $40 \mu \mathrm{M}$.

There was a strong diel pattern in the cell division of Rhizosolenia formosa (Fig. 6). The highest percentages (29 to $35 \%$ ) of recently divided cells were observed early in the light period; the minimum $(5 \%)$ was half way through the dark period. On average, $89 \%$ of the recently divided cells were negatively buoyant. Positive buoyancy remained fairly constant (19 to

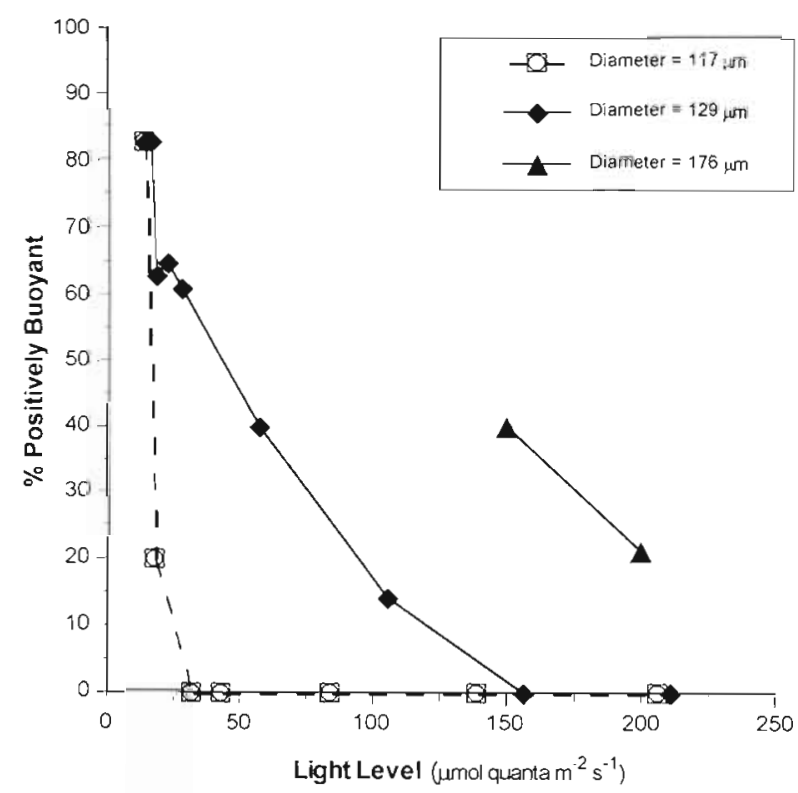

Fig. 4. Rhizosolenia formosa. Percentage of positively buoyant cells of different sizes under nutrient-replete conditions at different irradiance levels. Buoyancy measurements are from single samples 


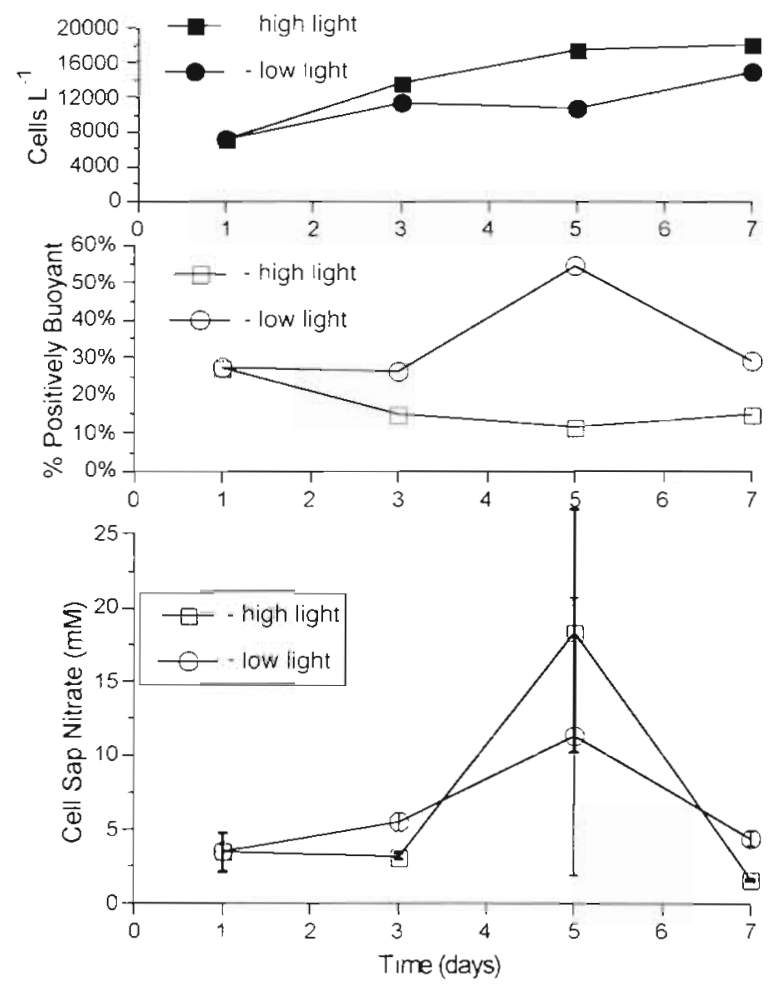

Fig. 5. Rhizosolenia formosa. Growth, buoyancy and cell sap nitrate in high- and low-light cultures. Error bars for cell sap nitrate indicate the standard deviation from duplicate samples. Cell numbers are calculated from the average of triplicate samples. Buoyancy measurements are from single samples

$25 \%$ ), with 2 higher percentages observed halfway through the dark period (43\%) and halfway through the light period $(38 \%)$. Average cell sap nitrate concentrations (from duplicate samples) increased steadily during the dark period from $4 \mathrm{mM}$ to a maximum of $17 \mathrm{mM}$; this strongly implies that $R$. formosa is capable

Table 1. Comparison of the chemical composition of Rhizosolenia acuminata and $R$. formosa. All values are ng cell ${ }^{-1}$ In each case the value measured in light-saturated, nutrient-replete cultures is compared with the size-dependent predicted value, given in parentheses, from previous studies (Strathmann 1967, Hitchcock 1982). Single values denote the average of triplicate samples, a range of values indicates samples taken on different days during the exponential growth phase, and '-' indicates not measured

\begin{tabular}{|lccc|}
\hline & \multicolumn{2}{c}{ R. formosa } & \multirow{2}{*}{ R. acuminata } \\
& $129 \mu \mathrm{m}$ diam. & $176 \mu \mathrm{m}$ diam. & $122 \mu \mathrm{m}$ diam. \\
\hline Chlorophyll a & $0.99-1.27(1.98)^{\mathrm{d}}$ & - & $0.25(2.04)^{\mathrm{d}}$ \\
Protein & - & $103-158(1.02)^{\mathrm{d}}$ & $65(66)^{\mathrm{d}}$ \\
Carbohydrate & - & $61-149(72)^{\mathrm{d}}$ & $65(46)^{\mathrm{d}}$ \\
Carbon & $258^{\mathrm{c}}(56)^{\mathrm{b}}$ & $133-370(87)^{\mathrm{b}}$ & $33(57)^{\mathrm{b}}$ \\
${ }^{\mathrm{a}}$ Hitchcock (1982), ${ }^{\mathrm{h}}$ Strathmann (1967), ${ }^{\mathrm{c}}$ from single sample \\
\hline
\end{tabular}

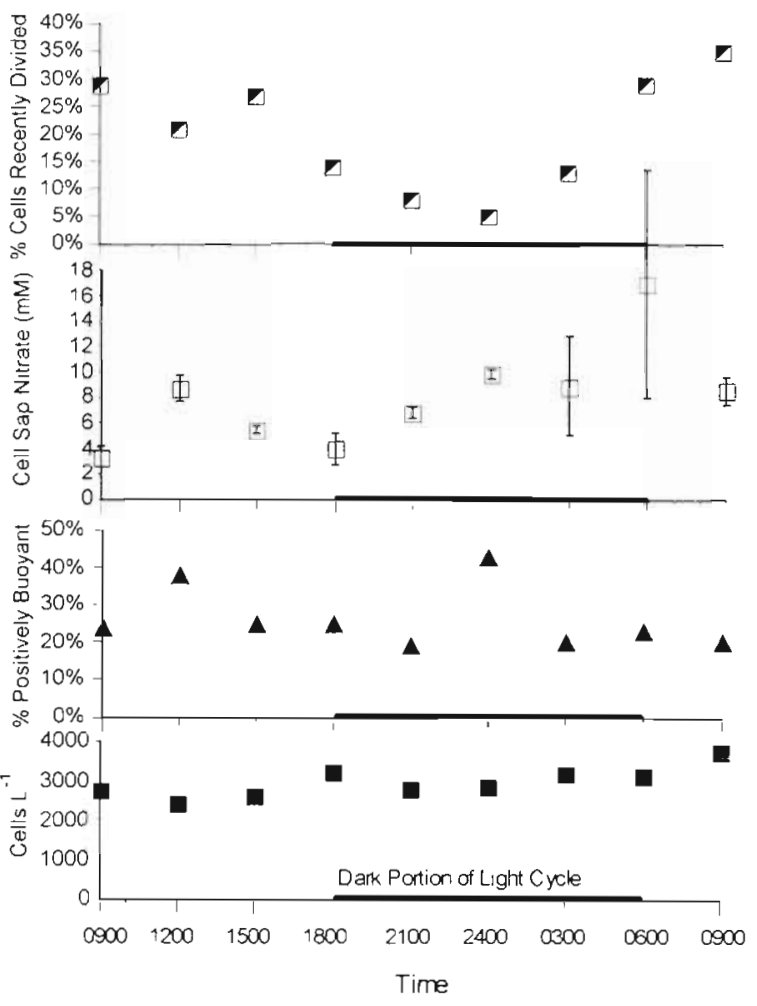

Fig. 6. Rhizosolenia formosa. Changes in a culture over a $24 \mathrm{~h}$ period. Cell sap nitrate is the average of duplicate samples. Error bars indicate the standard deviation

of nitrate uptake in the dark. The minimum average intracellular nitrate concentration was $3.3 \mathrm{mM}$; thus, intracellular nitrate concentrations can vary at least 5 fold during a diel cycle.

Most chemical composition values of Rhizosolenia acuminata and $R$. formosa were close to the values predicted by previous size-dependent studies of diatoms (Strathmann 1967, Hitchcock 1982; see Table 1). One notable exception was the higher-thanpredicted particulate $C$ values in $R$. formosa. These elevated $C$ values are consistent with the observed high $C: N$ ratios 19.0 to $16.4, \mathrm{~mol} / \mathrm{mol}$ ) and greater than predicted carbohydrate levels (Table 1). Chlorophyll a values were lower than predicted, especially in $R$. acuminata. The highest average chlorophyll a value observed in $R$. acuminata was $0.70 \mathrm{ng} \mathrm{cell}^{-1}$ (in a low-light culture), while Hitchcock's (1982) size relationship would predict $2.04 \mathrm{ng}$ cell ${ }^{-1}$. The Rhizosolenia spp. in this study were within the size range considered in the 2 size-composition studies (Strathmann 1967. Hitchcock 1982). The maximum assimilation numbers calculated 


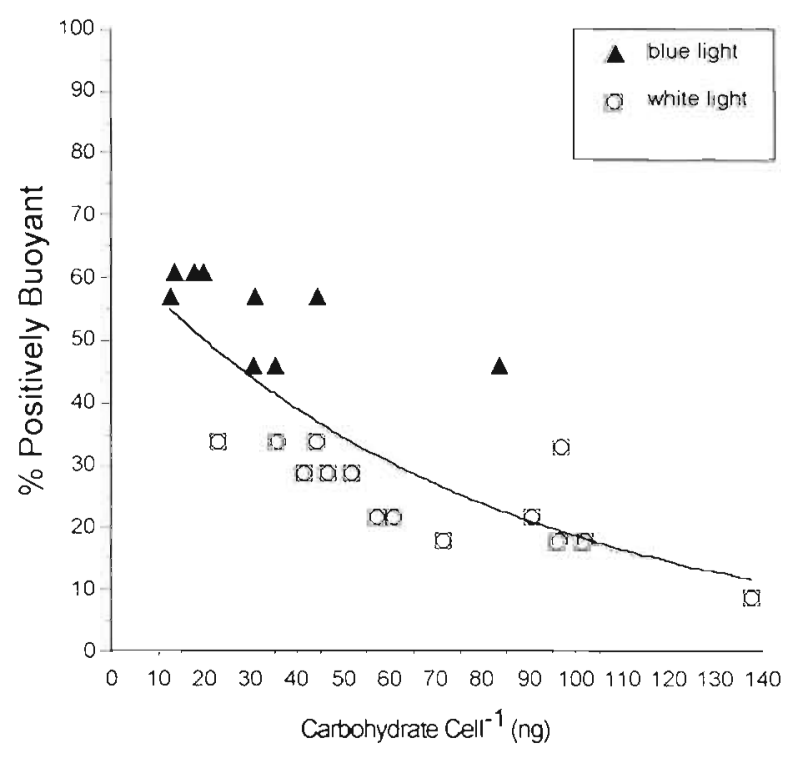

Fig. 7 Rhizosolenia acuminata. The percentage of cells positively buoyant plotted against carbohydrate quotas (ng cell ${ }^{-1}$ ). Buoyancy is the average of duplicate samples. The best fit curve is \%Pos $=64.2 \mathrm{e}^{-0.0124 \operatorname{Carb}}, \mathrm{r}^{2}=0.67$, where \%Pos is the percentage of cells positively buoyant, and Carb is ng carbohydrate cell ${ }^{-1}$

for $R$. formosa and $R$. acuminata were 2.9 and $6.9 \mathrm{mg} \mathrm{C}$ $\mathrm{mg}^{-1}$ chlorophyll a $\mathrm{h}^{-1}$, respectively (see Table 3 ). There was a negative correlation between carbohydrate per cell and positive buoyancy when all values for $R$. acuminata were examined (Fig. 7).

\section{DISCUSSION}

Rhizosolenia formosa, $R$. acuminata and $R$. castracanei had similar buoyancy properties (Table 2). All 3 species exhibited an inverse relationship between light level and positive buoyancy under nutrientreplete conditions, and all had low percentages of positively buoyant cells in stationary phase cultures. $R$. formosa and $R$. acuminata also experienced growth inhibition at relatively low light intensities. Photoinhibition is typically exhibited at light intensities $>500$ umol quanta $\mathrm{m}^{-2} \mathrm{~s}^{-1}$ (Platt et al. 1980, Neale \& Richerson 1987). Light-induced cell mortality was observed in $R$. formosa at light levels as low as $105 \mu \mathrm{mol}$ quanta $\mathrm{m}^{-2} \mathrm{~s}^{-1}$. This cell mortality did not occur until cells had been exposed to these light levels for a considerable time period of 20 to $30 \mathrm{~d}$. Initially (up to $10 \mathrm{~d}$ ), cells appeared healthy and some cell division occurred. A similar photoinhibition-induced mortality has been reported for Pyrocystis noctiluca. Kahn \& Swift (1978) reported that nutrient-depleted cells died within a few days at $60 \mu \mathrm{mol}$ quanta $\mathrm{m}^{-2} \mathrm{~s}^{-1}$, but not at lower light levels. In another experiment $P$. noctiluca cells under both nutrient-replete and nutrient-deplete conditions died when suspended in situ (depth of $10 \mathrm{~m}$ ) at $-312 \mu \mathrm{mol}$ quanta $\mathrm{m}^{-2} \mathrm{~s}^{-1}$ (Ballek \& Swift 1986). Like $P$. noctiluca, $R$. formosa (and probably the others) became negatively buoyant during cell division (Swift et al. 1976, Kahn \& Swift 1978, Rivkin et al, 1984). Based on these similarities, the once-in-a-generation migration pattern noted in $P$. noctiluca appears to be a valid model for solitary Rhizosolenia as well.

Rhizosolenia formosa seems well adapted for growth at low light levels as evidenced by the steep slope of the light-limited portion of the growth-irradiance curve (Fig. 1A). The maximum growth rate for $R$. formosa in Fig. 1 was 0.37 divisons $\mathrm{d}^{-1}$ at the very low light level of $29 \mu \mathrm{mol}$ quanta $\mathrm{m}^{-2} \mathrm{~s}^{-1}$. This irradiance level is equivalent to $\sim 1 \%$ of surface irradiance levels in the Sargasso Sea (at noon during spring-summer) (Goldman 1993). Thus maximum growth rates were observed in environmental conditions similar to those found near the nutricline.

There were similarities observed between the chemical composition of Rhizosolenia acuminata and $R$. formosa in this study under nutrient-replete, lightsaturated conditions and that of field populations of Rhizosolenia mats, Ethmodiscus rex and Pyrocystis

Table 2. Buoyancy and growth characteristics summary for Rhizosolena formosa (at 2 cell sizes), $R$, acuminata and $R$. castracanei

\begin{tabular}{|c|c|c|c|c|}
\hline \multirow[b]{2}{*}{ Cell diameter $(\mu \mathrm{m})$} & \multicolumn{2}{|c|}{ R. formosa } & \multirow{2}{*}{$\begin{array}{l}\text { R. acuminata } \\
122\end{array}$} & \multirow{2}{*}{$\frac{\text { R. castracane }}{112}$} \\
\hline & 129 & 176 & & \\
\hline Average cell volume $\left(\times 10^{6} \mu \mathrm{m}^{3}\right)$ & 6.60 & 11.8 & 6.83 & 7.66 \\
\hline Max. growth rate (divisions $\alpha^{-1}$ ) & 0.37 & 0.51 & 0.78 & 0.38 \\
\hline Light level of max growth rate ( $\mu \mathrm{mol}$ quanta $\mathrm{m}^{-2} \mathrm{~s}^{-1}$ ) & 29 & 150 & 155 & 164 \\
\hline Lowest light level with photoinhibition of growth & 105 & 200 & 210 & - \\
\hline $\begin{array}{l}\% \text { of cells positively buoyant: } \\
\text { (1) under nutrient replete, low-light conditions }\left(<40 \mu \mathrm{mol} \text { quanta } \mathrm{m}^{-2} \mathrm{~s}^{-1}\right) \\
\text { (2) under nutrient replete, high-light conditions }\left(>100 \mu \mathrm{mol} \text { quanta } \mathrm{m}^{-2} \mathrm{~s}^{-1}\right) \\
\text { (3) in stationary phase cultures }\end{array}$ & $\begin{array}{c}61-83 \% \\
0-14 \% \\
<25 \%\end{array}$ & $\begin{array}{c}- \\
21-40 \% \\
<25 \%\end{array}$ & $\begin{array}{c}50-56 \% \\
22-51 \% \\
<32 \%\end{array}$ & $\begin{array}{c}48-71 \% \\
33-38 \% \\
<21 \%\end{array}$ \\
\hline
\end{tabular}


noctiluca (Table 3), including high $\mathrm{C}: \mathrm{N}$ and $\mathrm{C}$ :chlorophyll ratios and similar cell sap nitrate concentrations and assimilation numbers. Villareal \& Carpenter (1994) reported that $E$. rex cells contained only $\sim 40 \%$ of the predicted amounts of chlorophyll a and 1.2 to 2.5 times as much $\mathrm{C}$ cell ${ }^{-1}$ as predicted by the same size-composition equations as in Table 1 (Strathmann 1967. Hitchcock 1982). Typically C:chlorophyll ratios in cultures growing at high relative growth rates range from 25 to 50 (wt/wt) and C: $\mathrm{N}$ ratios from 5 to 7 (mol/mol) (Goldman 1980). The high C: $N$ ratios seen in $R$. formosa in this study under nutrient-replete conditions strongly support the hypothesis that the high $\mathrm{C}: \mathrm{N}$ ratios seen in field populations of the buoyant phytoplankton species listed in Table 3 do not indicate $\mathrm{N}$ limitation (Villareal \& Carpenter 1989, 1994). Rivkin et al. (1984) suggest that Pyrocystis accumulates excess carbon at high (near-surface) light intensities which it catabolizes at depth during nutrient uptake, thus maintaining a relatively high growth rate throughout the water column. Rhizosolenia and Ethmodiscus spp. appear to have similar utilization patterns. The maximum assimilation number of $R$. acuminata was quite close to the assimilation numbers seen in Rhizosolenia mats in situ (Table 3), and suggests that the mats were growing at high relative growth rates.

Cell sap nitrate concentrations were consistently an order of magnitude higher than medium nitrate concentrations in both Rhizosolenia acuminata and $R$. formosa. $R$. formosa had average concentrations as high as 17 to $18 \mathrm{mM}$ and a maximum of $26 \mathrm{mM}$, seen in several samples. $R$. acuminata had lower average (2.2 to $6.4 \mathrm{mM})$ and maximum $(8.4 \mathrm{mM})$ concentrations. These concentrations are at the lower end of the

Table 3. Comparison of the chemical composition of Rhizosolenia acuminata and $R$. formosa in light-saturated, nutrient-replete cultures with field populations of Rhizosolenia mats, Ethmodiscus rex and Pyrocystis noctiluca

\begin{tabular}{|c|c|c|c|c|}
\hline & $\begin{array}{c}\mathrm{C}: \mathrm{N}^{a} \\
(\mathrm{~mol} / \mathrm{mol})\end{array}$ & $\begin{array}{l}\text { C:chl } \\
(w t / w t)\end{array}$ & $\begin{array}{l}\text { Assimilation } \\
\text { number } \\
\left.\text { (mg C mg }{ }^{-1} \mathrm{chl} a \mathrm{~h}^{-1}\right)\end{array}$ & $\begin{array}{l}\text { Intracellular } \\
\text { nitrate } \\
\text { (mM) }\end{array}$ \\
\hline R. acuminata & 6.2 & 130 & 6.9 & 2.3 \\
\hline R. formosa & $9-16.4$ & 261 & 2.9 & $3.3-26.5$ \\
\hline \multicolumn{5}{|l|}{ R. mats } \\
\hline Atlantic ${ }^{b}$ & 9.7 & 590 & 6.6 & - \\
\hline Pacific & $7.4^{r}$ & $150^{\circ}$ & $6.3^{d}$ & $0.3-14.1^{2}$ \\
\hline Pacific ${ }^{f}$ & $5.8-13.1$ & - & 6 & - \\
\hline E. $\operatorname{rex}^{9}$ & 14.4 & 129 & $1.8-4.7$ & $1.4-27.1$ \\
\hline P. noctiluca ${ }^{\mathrm{n}}$ & 10 & $121-165$ & 3.3 & - \\
\hline \multicolumn{5}{|c|}{ 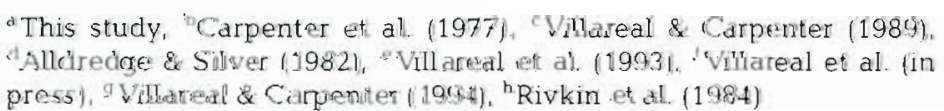 } \\
\hline
\end{tabular}

intracellular nitrate concentrations seen in other diatoms under $\mathrm{N}$-replete conditions (up to $94 \mathrm{mM}$ ): however, the percent of particulate $\mathrm{N}$ accounted for by intracellular nitrate is near the upper end $(5.4 \%)$ of the range observed in other diatoms (Dortch et al. 1984). In general, the cell sap nitrate concentrations observed in. $R$. acuminata and $R$. formosa were comparable with the concentrations seen in field populations of Rhizosolenia mats and Ethmodiscus rex (Table 3). Individual Rhizosolenia chains collected in the Sargasso Sea had average intracellular nitrate concentrations of $4.2 \mathrm{mM}$ and the positively buoyant chains had significantly higher internal nitrate concentrations than sinking chains (Villareal \& Lipschultz 1995). This is further evidence that these field populations are not $\mathrm{N}$-limited, because $\mathrm{N}$-starved diatoms do not accumulate nitrate internally (Dortch 1982, Dortch et al. 1984).

Dark nitrate uptake and storage occurred in the Rhizosolcnia formosa diel experiment (Fig. 6) where maximum cell sap nitrate concentrations $(17.0 \mathrm{mM})$ were observed at the end of the dark period. Cullen (1985) calculated a rough stoichiometry whereby for each nitrate ion taken up and reduced nocturnally, about $6 \mathrm{CH}_{2} \mathrm{O}$ units were utilized. The observed average nocturnal uptake by $R$. formosa $\left(0.15 \mathrm{nmol} \mathrm{NO}_{3}{ }^{-} \mathrm{cell}^{-1}\right)$ would utilize $0.92 \mathrm{nmol} \mathrm{CH}_{2} \mathrm{O}$ or roughly $27.7 \mathrm{ng}$ carbohydrate if fully reduced. Cells equal in size to those in the diel experiment contained up to $149 \mathrm{ng}$ carbohydrate. This was enough carbohydrate to extend the uptake and full reduction of nitrate in the dark for up to 5.3 times the length of the dark period (149 $\mathrm{ng}$ / $27.7 \mathrm{ng}=5.3$ ) or approximately $2.7 \mathrm{~d}$. Based on this conservative calculation, cells below the nutricline for more than a day might accumulate considerably higher internal nitrate concentrations. For example, assuming a constant uptake rate, a cell below the nutricline for $36 \mathrm{~h}$ would increase its intracellular nitrate concentration from 4.7 to $43.7 \mathrm{mM}$. Since all other sampling was done during the light period, cell sap nitrate concentrations in other experiments were likely not at their maximum values.

The inverse relationship between positive buoyancy and irradiance level in all 3 Rhizosolenia spp. under nutrient-replete conditions implies that physiological changes in cells at supersaturating light intensities result in negative buoyancy. Accumulation of excess carbohydrates at high light intensities seems a logical cause, especially since this type of carbohydrate ballasting has been widely documented for buoyant cyanobacteria (van Rijn \& Shilo 1985, lbelings et al. 1991, Oliver 1994). 
There was a negative correlation $\left(r^{2}=0.67\right)$ between ng carbohydrate cell ${ }^{-1}$ and positive buoyancy in $R$. acuminata (Fig. 7). Theoretical calculations demonstrate the feasibility of the carbohydrate ballasting hypothesis for Rhizosolenia. Oliver (1994) described how the 'excess' density contributed by a cellular component such as carbohydrate can be calculated as the difference in density between its mass and the mass of the volume of water it displaces. Given a carbohydrate density of $1.6 \mathrm{~g} \mathrm{ml}^{-1}$ (Oliver 1994) and that the density of water is approximately $1.0 \mathrm{~g} \mathrm{ml}^{-1}$, the excess density contributed by carbohydrates is $1.6-1.0=0.6 \mathrm{~g} \mathrm{~m}^{-1}$. Thus, the observed average carbohydrate increase (75.9 ng carbohydrate cell ${ }^{-1}$ ) in $R$. acuminata from the lowest to the highest light level would displace approximately $47.4 \times 10^{-9} \mathrm{ml}$ of water $\left[\left(75.9 \times 10^{-9}\right.\right.$ g) $/ 1.6 \mathrm{~g} \mathrm{ml}^{-1}=47.4 \times 10^{-9} \mathrm{ml}$. Since the density of water is $1.0 \mathrm{~g} \mathrm{~m}^{-1}$, the weight of this volume of water would be $47.4 \times 10^{-9} \mathrm{~g}$, or $47.4 \mathrm{ng}$. Thus, the excess density contributed by the carbohydrate increase would be $75.9-47.4=28.5 \mathrm{ng}$ cell $^{-1}$. Assuming a constant seawater density of $1.0235 \mathrm{~g} \mathrm{~cm}^{-3}$ (a typical density in Sargasso Sea surface waters; Villareal 1988), and subtracting the average density difference between positively buoyant cells and seawater of $2,3 \mathrm{mg} \mathrm{m}^{-1}$ calculated for $R$. acuminata (Moore 1994), the average cell density would be $1.0212 \mathrm{~g} \mathrm{~cm}^{-3}$ Given an average cell volume of $6.245 \times 10^{6} \mu^{3}{ }^{3}$, the average cell's weight would be $6377.4 \mathrm{ng}$. Adding the $28.5 \mathrm{ng}$ cell $l^{-1}$ of excess density from carbohydrates to this cell weight would increase cell density to $1.0258 \mathrm{~g} \mathrm{~cm}^{-3}$ (an increase of $4.6 \mathrm{mg} \mathrm{m}^{-1}$ ). Thus the average increase in carbohydrate cell ${ }^{-1}$ between the lowest and highest light levels observed in $R$. acuminata would be more than sufficient to cause the average positively buoyant cell to become negatively buoyant. This calculation assumes that other cellular constituents remain the same at the 2 light levels, but it does indicate that carbohydrate ballasting alone could account for the observed buoyancy patterns. Lowering carbohydrate content by the same amount would restore positive buoyancy. The increase in positive buoyancy seen in the $R$. formosa culture moved from high to low light (Fig. 5) is consistent with this hypothesis. Further evidence for the carbohydrate ballasting hypothesis is seen in recent data from Rhizosolenia mats in the central North Pacific where negatively buoyant mats had very high carbohydrate/protein ratios (average 2.2) relative to positively buoyant mats (average 0.7 ) (Villareal et al. in press)

Under steady-state conditions, the buoyancy properties summarized in Table 1, if replicated in situ, would lead to sub-surface population maxima in all 3 Rhizosolenia spp. similar to what has been documented for Pyrocystis noctiluca (Swift et al. 1976, Rivkin et al.
1984). Cells would not maintain a single preferred depth but would oscillate around a preferred depth or light level; on average, cells below the preferred depth would be positively buoyant and cells above that depth would be negatively buoyant. Examining Fig. 2A, it appears that nutrient-replete $R$. formosa would likely be positively buoyant at light levels $<20-40 \mu \mathrm{mol}$ quanta $\mathrm{m}^{-2} \mathrm{~s}^{-1}$ and negatively buoyant at light levels $>20-40 \mu \mathrm{mol}$ quanta $\mathrm{m}^{-2} \mathrm{~s}^{-1}$ Thus, the apparent preferred depth was where light levels were approximately 20 to $40 \mu \mathrm{mol}$ quanta $\mathrm{m}^{-2} \mathrm{~s}^{-1}$. Maximum growth rates were observed (Fig $1 \mathrm{~A}$ ) in this same light range. The relationship between light level and buoyancy (and inferred preferred depth) was also a function of cell size (Fig. 4). This oscillating depth regulation is consistent with vertical migration if the lower end of the oscillation brings cells below the nutricline sufficiently frequently (see the model of Kromkamp \& Walsby 1990, 1992), an event that clearly occurs based on field populations of solitary Rhizosolenia (Villareal \& Lipschultz 1995). The growth and buoyancy characteristics of all 3 species are consistent with being part of the 'shade flora', a flora which occurs preferentially or exclusively at some depth below the surface, usually around $100 \mathrm{~m}$ depth near the nutricline, and includes $R$. acuminata and R. castracanei (Sournia 1982, Venrick 1982). However, the steady-state assumptions of cultures may not be valid for open-ocean populations. These cultures were preadapted to a single light intensity for $10 \mathrm{~d}$, an unlikely occurrence in the open sea, where cell buoyancy appears to respond to nutrient depletion on the order of a few days (Villareal \& Lipschultz 1995). Nonetheless, these culture studies indicate that even under conservative steady-state conditions, $R$. acuminata, $R$. castracanei and $R$. formosa are capable of positive buoyancy and under laboratory conditions exhibit buoyancy and growth characteristics consistent with vertical migration. $R$. acuminata and $R$. formosa had chemical compositions similar to those observed in vertically migrating populations of Rhizosolenia mats, Pyrocystis noctiluca and Ethmodiscus rex in oligotrophic seas (Rivkin et al. 1984, Villareal et al. 1993, Villareal \& Carpenter 1994), In addition, all 3 species in this study are capable of ascent rates on the order of $\mathrm{cm}$ to $\mathrm{m} \mathrm{h}^{-1}$ (Moore 1994) which permit the euphotic zone to be traversed in as little as $24 \mathrm{~h}$. Thus, it seems likely that short chains of $R$. formosa, $R$. castracanei and $R$. acuminata are capable of a buoyancy-mediated vertical migration and, thus, are a source of new nitrogen to the euphotic zone. Unfortunately, quantitative abundance data for these species are not available. While Rhizosolenia mats are found mainly in the Pacific, single-species chains of large Rhizosolenia are commonly found in all warm water seas, particularly in the Sargasso Sea (Sundström 1986, 
Villareal 1988). Thus, vertical migration by single-species chains of Rhizosolenia may be a significant source of new nitrogen on a global scale.

Acknowledgements. This work was supported by NSF grant OCE 9100888 awarded to T.A.V. The authors thank Sam Woods, Zehra Schneider, Sue Hegarty, and Karen Imbalzano for assistance processing samples. In addition, we thank 3 anonymous reviewers for their comments.

\section{LITER ITURE CITED}

Alldredge AL, Silver MW (1982) Abundance and production Rhizosoleniarates of floating diatom mats (Rhizosolenia castracanei and $R$. imbricata var. shrubsolel in the Eastern Pacific Ocran. Mar Biol 66:83-88

Ballek RW, Swift I: (1986) Nutrient- and light-mediated buoyancy control of the oceanic non-motile dinoflagellate Pyrocystis noctiluca Murray ex Haeckel (1890). J Exp Mar Biol Ecol 101:175-192

Banse K (1987) Clouds, deep chlorophyll maxima and the nutrient supply to the mixed layer of stratified water bodies. J Plankton Res 9:1031-1036

Carpenter EJ, Harbison GR, Madin LP, Swanberg NR, Biggs DC, Hulburt EM, MCAlister VL, MCCarthy JJ (1977) Rhizosolenia mats. Limnol Oceanogr 22:739-741.

Chisholm SW (1992) Phytoplankton size. In: Falkowski PG, Woodhead AD (eds) Primary productivity and biogeochemical cycles in the sea. Plenum Press, New York, p $213-237$

Cullen JJ (1985) Diel vertical migration by dinoflagellates: roles of carbohydrate metabolism and behavioral flexibility. In: Rankin MA (ed) Migration: mechanisms and adaptive significance. Marine Science Institute, The University Of Texas At Austin, Port Aransas, p 135-152

Dortch $Q$ (1982) Effects of growth conditions on accumulation of internal nitrate, ammonium, amino acids, and protein in three marine diatoms. J Exp Mar Biol Ecol 61:243-264

Dortch Q. Clayton JR Jr, Thorensen SS, Ahmed SI (1984) Species differences in accumulation of nitrogen pools in phytoplankton. Mar Biol 81:237-250

Dugdale RC, Goering JJ (1967) Uptake of new and regenerated forms of nitrogen in primary productivity. Limnol Oceanogr 12:196-206

Ganf GG, Oliver RL (1982) Vertical separation of light and available nutrients as a factor causing replacement of green algae by blue-green algae in the plankton of a stratified lake. J Ecol 70:829-844

Goldman JC (1980) Physiological processes, nutrient availability, and the concept of relative growth rate in marine phytoplankton ecology. In: Falkowski PG (ed) Primary productivity in the sea. Plenum. Press, New York, p 179-194

Goldman JC (1993) Potential role of large oceanic diatoms in new primary production. Deep Sea Res 40:159-168

Hayward TL (1993) The rise and fall of Rhizosolenia. Nature 363:675-676

Hayward TL (1994) The shallow oxygen maximum layer and primary production. Deep Sea Res 41:559-574

Hitchcock GL (1982) A comparative study of the size-dependent organic composition of marine diatoms and dinoflagellates. J Plankton Res 4:363-377

Ibelings RW, Mur LR, Walsby AE (1991) Diurnal changes in buoyancy and vertical distribution in populations of Microcystis in two shallow lakes. J Plankton Res 13:419-436
Kahn N, Swift E (1978) Positive buoyancy through 1onic control in the nonmotile marine dinoflagellate Pyrocystis noctıluca Murray ex Schuett. Limnol Oceanogr 23:649-658

Karsten G (1905) Das Phytoplankton des atlantischen Ozeans nach dem Material der deutschen Tiefsee-Expedition 1898-1899. Wiss Ergebn dt Tiefsee-Exped 'Valdiva' 1898 1899 2:137-219

Karsten G (1907) Das indische Phytoplankton nach dem Material der deutschen Tiefsee-Expedition 1898-1899. Wiss Ergebn dt Tiefsee-Exped. 'Valdivia' 2:221-548

Kromkamp J, Walsby AE (1990) A computer model of buoyancy and vertical migration in cyanobacteria. J Plankton Res 12:161-183

Kromkamp J, Walsby AE (1992) Buoyancy regulation and vertical migration of Trichodesmium: a computer-model prediction. In: Carpenter EJ et al. (eds) Marine pelagic cyanobacteria: Trichodesmium and other diazotrophs. Kluwer Academic Publishers, Dordrecht, p 239-248

Moore JK (1994) Buoyancy and growth characteristics of the marine diatoms Rhizosolenia formosa $\mathrm{H}$. Peragallo and $R$. acuminata (H. Per) H. Peragallo. MSc thesis, University of Massachusetts at Boston

Neale JN, Richerson PJ (1987) Photoinhibition and the diurnal variation of phytoplankton photosynthesis. I. Development of a photosynthesis-irradiance model from studies of in situ responses. J Plankton Res 9:167-1.93

Oliver RL (1994) Floating and sinking in gas-vacuolate cyanobacteria. J Phycol 30:161-173

Parsons TR, Maita Y, Lalli CM (1984a) Determination of total particulate carbohydrate by anthrone reagent. In: A manual of chemical and biological methods for seawater analysis. Pergamon Press, Oxford, p 67-71

Parsons TR, Maita Y, Lalli CM (1984b) Fluorometric determination of chlorophylls. In: A manual of chemical and biological methods for seawater analysis. Pergamon Press, New York, p 107-109

Platt T, Gallegos CL, Harrison WG (1980) Photoinhibition of photosynthesis in natural assemblages of marine phytoplankton. J Mar Res 38:687-701

Rivkin RB, Swift E, Biggley WH, Voytek MA (1984) Growth and carbon uptake by natural populations of oceanic dinoflagellates Pyrocystis noctiluca and Pyrocystis fusiformis. Deep Sea Res 31:353-367

Round FE, Crawtord RM, Mann DG (1992) The diatoms: biology \& morphology of the generd. Cambridge University Press, Cambridge, p 107-110

Schöne HK, Schöne A (1982) MET 44: a weakly enriched seawater medium for ecological studies on marine plankton algae and some examples of its application. Botanica Mar 25:117-122

Smayda TJ (1970) The sinking and suspension of phytoplankton in the sea. Oceanogr Mar Biol A Rev 8:353-414

Smuth PK et al. (1985) Measurement of protein using bicinchoninic acid. Analyt Biochem 150:76-85

Sournia A (1982) Is there a shade flora in the marine plankton? J Plankton Res 4:391-399

Strathmann RR (1967) Estimating the organic carbon content of phytoplankton from cell volume or plasma volume. Limnol Oceanogr 12:411-418

Sundström BG (1986) The marine djatom genus Rhizosolenia - a new approach to the taxonomy. PhD dissertation. Lund University

Swift E, Stuart M, Meunier V (1976) The in situ growth rates of some deep-living dinoflagellates: $P_{\text {yrocystis fusiformis }}$ and Pyrocystis noctiluca. Limnol Oceanogr 21:418-426

van Rijn J, Shilo M (1985) Carbohydrate fluctuations, gas vacuolation, and vertical migration of scum-forming cyano- 
bacteria in fishponds. Limnol Oceanogr 30:1219-1228

Venrick EL (1982) Phytoplankton in an oligotrophic ocean observations and questions. Ecol Monogr 52:129-154

Villareal TA (1988) Positive buoyancy in the oceanic diatom Rhizosolenia debyana H. Peragallo. Deep Sea Res 35: $1037-1045$

Villareal TA. (1991) Nitrogen-fixation by the cyanobacterial symbiont of the diatom Hemiaulus. Mar Ecol Prog Ser 76 201-204

Villareal TA (1992) Buoyancy properties of the giant diatom Ethmodiscus. J Plankton Res 14:459-463

Villareal TA, Altabet MA, Culver-Rymsza K (1993) Nitrogen transport by vertically migrating diatom mats in the North Pacific ocean. Nature 363:709-712

Villareal TA, Carpenter EJ (1989) Nitrogen fixation, suspension characteristics, and chemical composition of Rhi-

This article was submitted to the editor zosolenia mats in the central North Pacific gyre. Biol Oceanogr 6:237-345

Villareal TA, Carpenter EJ (1994) Chemical composition and photosynthetic characteristics of Ethmodiscus rex (Bacillariophyceae): evidence for vertical migration. J Phycol 30 $1-8$

Villareal TA, Lipschultz F (1995) Internal nitrate concentrations in single cells of large phytoplankton from the Sargasso Sea. J Phycol 31:689-696

Villareal TA, Woods S, Moore JK, Culver-Rymsza K (1996) Vertical migration of Rhizosolema mats and their signuf cance to $\mathrm{NO}_{3}{ }^{-}$fluxes in the central North Pacific gyre. $J$ Plankton Res (in press)

Walsby AE, Reynolds CS (1980) Sinking and floating. In: Morris I (ed) The physiological ecology of phytoplankton. Blackwell Scientific, Boston, p 371-412

Manuscript first received: May 23, 1995

Revised version accepted: September 14, 1995 